\title{
Mitoclastic and Clastogenic Effects of Aspirin on Mouse Bone-marrow Cells in vivo
}

\author{
Sailas Benjamin ${ }^{1}$ and J. Stephen ${ }^{2 *}$ \\ ${ }^{1}$ Regional Research Laboratory (CSIR), Trivandrum-695019, India \\ ${ }^{2}$ Regional Cancer Centre, Trivandrum-695011, India
}

Accepted October 30, 1995

Aspirin (acetyl salicylic acid) originally extracted from the willow (Salix alba) bark is a widely used antipyretic, analgesic, antirheumatic and antithrombotic drug freely available without medical prescription. Recently, it has been recommended for the primary prevention of myocardial infarction in patients with stable angina pectoris (Juul-Moller et al. 1992). However, several adverse side effects including its interference in platelet function have been known for a long time (Griffin and D'Arcy 1979). Gilman et al. (1991) have also warned of its adverse effects, if not administered properly. Weissmann (1991) has presented an excellent review on the history, uses and adverse side effects of aspirin. Odashima (1976) was the first to show its carcinogenic potentiality from animal experiments, especially transplacental carcinogenesis. Epidemiological studies in human beings have indicated that when taken together with phenacetin, aspirin increases the risk of urothelial cancer, particularly of the renal pelvis (IARC 1987, McCredie et al. 1993). Experimental studies of the U.S. Environmental Protection Agency have also confirmed the carcinogenic potential of aspirin (Nesnow et al. 1987). On the other hand, some reports show that aspirin intake reduces colon cancer incidence in man (Kune et al. 1988, Thun et al. 1991) and that has been explained to be due to the inhibition of arachidonic acid metabolism by aspirin (Marnett 1992). Hence, it appeared reasonable to test this drug in mouse bone marrow system to find out whether it has any mitoclastic or clastogenic properties.

\section{Materials and methods}

Aspirin in the form of water soluble tablets with the trade name "Dispirin" manufactured by Rekitt and Colman of India Ltd. (batch Nos. M-2272 dated 8.1.1991 and M-2668 dated 1/1992) was used in the present experiments. Three different concentrations of aspirin viz., 100 $\mu \mathrm{g} / \mathrm{ml}, 10 \mu \mathrm{g} / \mathrm{ml}$ and $1 \mu \mathrm{g} / \mathrm{ml}$, were prepared in glass distilled water and sterilised by millipore filtration. The test animals used were inbred Swiss albino mice (Mus musculus $2 \mathrm{n}=40$ ) with a body weight around $30 \mathrm{~g}$ and aged three months. Four mice were taken in each batch and each one was given $1 \mathrm{ml}$ of $100 \mu \mathrm{g} / \mathrm{ml}, 10 \mu \mathrm{g} / \mathrm{ml}$ and $1 \mu \mathrm{g} / \mathrm{ml}$ of aspirin solution, respectively and the fourth one kept as control was given $1 \mathrm{ml}$ distilled water, all by intraperitoneal (I.P.) injection. Although for i.p. injections, sterile physiological saline is used as the solvent of several drugs, it was avoided in this experiment as there is the possibility of the formation of sodium salicylate by chemical interaction of aspirin with saline (sodium chloride). After $24 \mathrm{hr}$, every one of the mice was sacrificed by quick cervical dislocation and the femurs were excised. Both ends of the femur were cut open with scissors and the fixative (methyl alcohol and acetic acid in $3: 1$ ratio) was flushed through the narrow cut end of the bone, using a hypodermic syringe to eject the bone marrow intact and was preserved in the fixative duly labelled. On the next day, Leishman smears and Acetocarmine squashes were prepared from the bone marrow samples and the slides

\footnotetext{
* Corresponding author.
} 
were examined under the microscope. The experiments were conducted in triplicate.

\section{Observations}

Bone marrow pictures of mice kept as control were normal, whereas the marrow from aspirin treated mice showed a wide range of cytological abnormalities. A marked lowering of the mitotic index with increasing concentration of the drug was noted (Table 1).

Fig. 1 shows a general picture of the bone marrow from a mouse treated with $1 \mu \mathrm{g} / \mathrm{ml}$ aspirin. A few cells arrested at prophase and one arrested at anaphase with sticky bridges can be seen. Figs. 2 and 3 represent mitotic arrest at prophase along with stickiness of chromosomes. Such mitotic arrests after chromosome condensation led to the formation of pycnotic nuclei (Figs. 4, 5). In Fig. 5, two other nuclei with prominent central vacuoles can also be seen. Blebbing of pycnotic nuclei (Fig. 6) was another abnormality encountered. Micronuclei (Fig. 7) were seen in all treated marrows. Fig. 8 shows two adjacent cells in prophase, with some degree of chromosome stickiness, of which one appears to be polyploid. In Fig. 10, three adjacent cells are in prophase of which two are evidently polyploid. In these also, some degree of stickiness is there. Abnormal metaphase configurations such as clumped metaphase and hollow metaphase (Fig. 9) were often encountered. Pulverization of chromosomes resulting in the formation of chromatin globules of varying sizes as in Fig. 11 was observed in bone marrow cells of mice administered with $10 \mu \mathrm{g} / \mathrm{ml}$ aspirin. Mitotic arrest at anaphase was also noticed (Fig. 12). Anaphases with sticky bridges (Fig. 13) were also encountered in treated bone marrow and such sticky bridges eventually disappear (Fig. 14). Pycnotic telophase nuclei with projecting telomeres were also observed occasionally (Fig. 15). The various cytological abnormalities induced by aspirin at the three different concentrations tested in mouse bone marrow in vivo are summarised in Table 2 along with controls.

\section{Discussion}

The above observations clearly show that aspirin is both mitoclastic and clastogenic even at the lowest concentration used. The mitoclastic property of the drug is evidenced from the

Table 1. Mitodepressive effect of aspirin on the bone marrow cells of inbred Swiss albino mice

\begin{tabular}{|c|c|c|c|c|c|}
\hline $\begin{array}{l}\text { Concentration of } \\
\text { aspirin }\end{array}$ & $\begin{array}{l}\text { Duration of } \\
\text { treatment }\end{array}$ & $\begin{array}{l}\text { Number of } \\
\text { mice used }\end{array}$ & $\begin{array}{l}\text { Total number of } \\
\text { bone marrow } \\
\text { cells examined }\end{array}$ & $\begin{array}{l}\text { Number of } \\
\text { dividing cells }\end{array}$ & Mitotic index \\
\hline \multirow[t]{3}{*}{0 (Distilled water) } & $24 \mathrm{hr}$. & 3 & 3451 & 2539 & 73.57 \\
\hline & & & 3434 & 2546 & 74.14 \\
\hline & & & 3436 & 2541 & 73.95 \\
\hline Mean & & & $3440 \pm 5.36$ & $2542 \pm 2.08$ & $73.84 \pm 0.17$ \\
\hline \multirow[t]{3}{*}{$1 \mu \mathrm{g} / \mathrm{ml}$} & $24 \mathrm{hr}$. & 3 & 3483 & 1829 & 52.51 \\
\hline & & & 3477 & 1838 & 52.86 \\
\hline & & & 3492 & 1830 & 52.41 \\
\hline Mean & & & $3484 \pm 4.36$ & $1832 \pm 2.85$ & $52.59 \pm 0.14$ \\
\hline \multirow[t]{3}{*}{$10 \mu \mathrm{g} / \mathrm{ml}$} & $24 \mathrm{hr}$. & 3 & 3522 & 674 & 19.14 \\
\hline & & & 3495 & 688 & 19.69 \\
\hline & & & 3525 & 700 & 19.86 \\
\hline Mean & & & $3514 \pm 9.54$ & $687.33 \pm 7.51$ & $19.56 \pm 0.22$ \\
\hline \multirow[t]{3}{*}{$100 \mu \mathrm{g} / \mathrm{ml}$} & $24 \mathrm{hr}$. & 3 & 3417 & 301 & 8.81 \\
\hline & & & 3404 & 289 & 8.49 \\
\hline & & & 3415 & 297 & 8.70 \\
\hline Mean & & & $3412 \pm 4.04$ & $295.7 \pm 3.53$ & $8.667 \pm 0.09$ \\
\hline
\end{tabular}



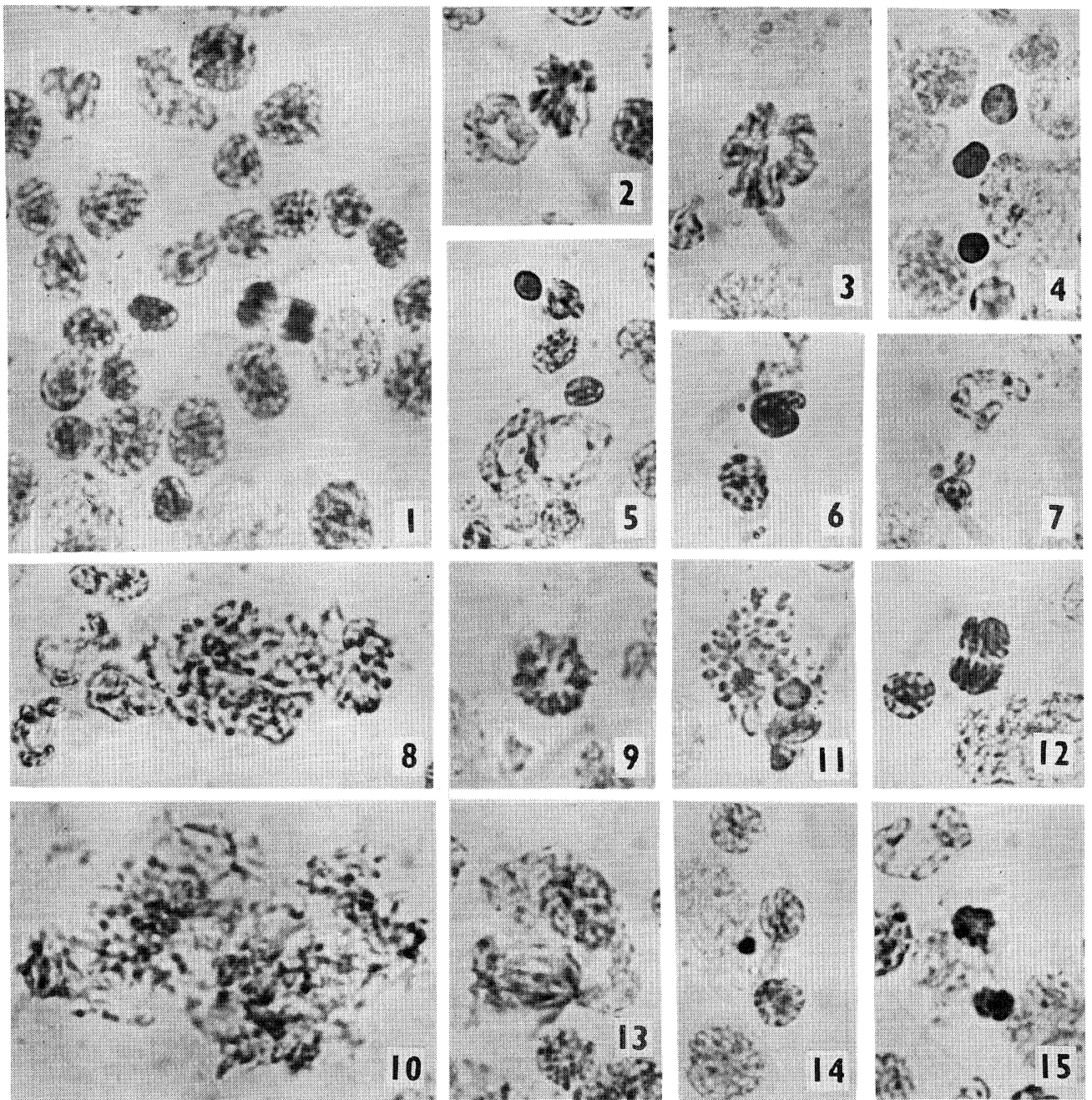

Figs. 1-15. Cytological abnormalities induced in bone marrow cells of inbred Swiss mice given IP injection and with different concentrations $(1 \mu \mathrm{g} / \mathrm{ml}, 10 \mu \mathrm{g} / \mathrm{ml}, 100 \mu \mathrm{g} / \mathrm{ml}$ ) of aspirin (All figures $\times 1150)$. (1) General view of the bone marrow $(1 \mu \mathrm{g} / \mathrm{ml}$ aspirin), (2) Stickiness and restitutions $(1 \mu \mathrm{g} / \mathrm{ml})$, (3) Restitution at prophase $(10 \mu \mathrm{g} / \mathrm{ml})$, (4) Nuclear pycnosis $(100 \mu \mathrm{g} / \mathrm{ml})$, (5) 2 Pycnotic nuclei $(100 \mu \mathrm{g} / \mathrm{ml})$, (6) Nuclear blebbing $(100 \mu \mathrm{g} / \mathrm{ml})$, (7) Budding of 2 micronuclei $(100 \mu \mathrm{g} / \mathrm{ml})$, (8) Prophase chromosomes from 2 adjacent cells exhibiting stickiness (100 $\mu \mathrm{g} / \mathrm{ml})$, (9) Hollow metaphase $(1 \mu \mathrm{g} / \mathrm{ml})$, (10) Polyploidy and Stickiness $(10 \mu \mathrm{g} / \mathrm{ml})$, (11) Pulverization of metaphase chromosomes resulting in the formation of chromatin globules (10 $\mu \mathrm{g} / \mathrm{ml})$, (12) Late Anaphase with a sticky bridge $(100 \mu \mathrm{g} / \mathrm{ml})$, (13) Anaphase $(10 \mu \mathrm{g} / \mathrm{ml})$ with multiple sticky bridges, (14) A pair of persistent bridges between 2 telophase nuclei $(10 \mu \mathrm{g} / \mathrm{ml})$,

(15) Broken bridge between two pycnotic telophase nuclei $(100 \mu \mathrm{g} / \mathrm{ml})$.

lowering of the mitotic index as well as from the arrest of the M-Phase substages and from the manifestation of spindle abnormalities. Of these, the lowering of the mitotic index might have been achieved by the inhibition of DNA synthesis at S-phase or by the arrest of cell cycle at $\mathrm{G}_{2}$-phase. Greater the concentration of the drug, the lower was the mitotic index. In this respect, aspirin was found to be stronger than paracetamol, analgin, palgin and phenylbutazone of equivalent concentration tested in this laboratory (Stephen et al. 1994). Mitotic arrest in all the sub-stages of M-phase suggests that aspirin action is not stage-specific. According to Nagl (1970), blockage of the cell cycle at $G_{2}$-phase results in endoreduplication, blockage at prophase 


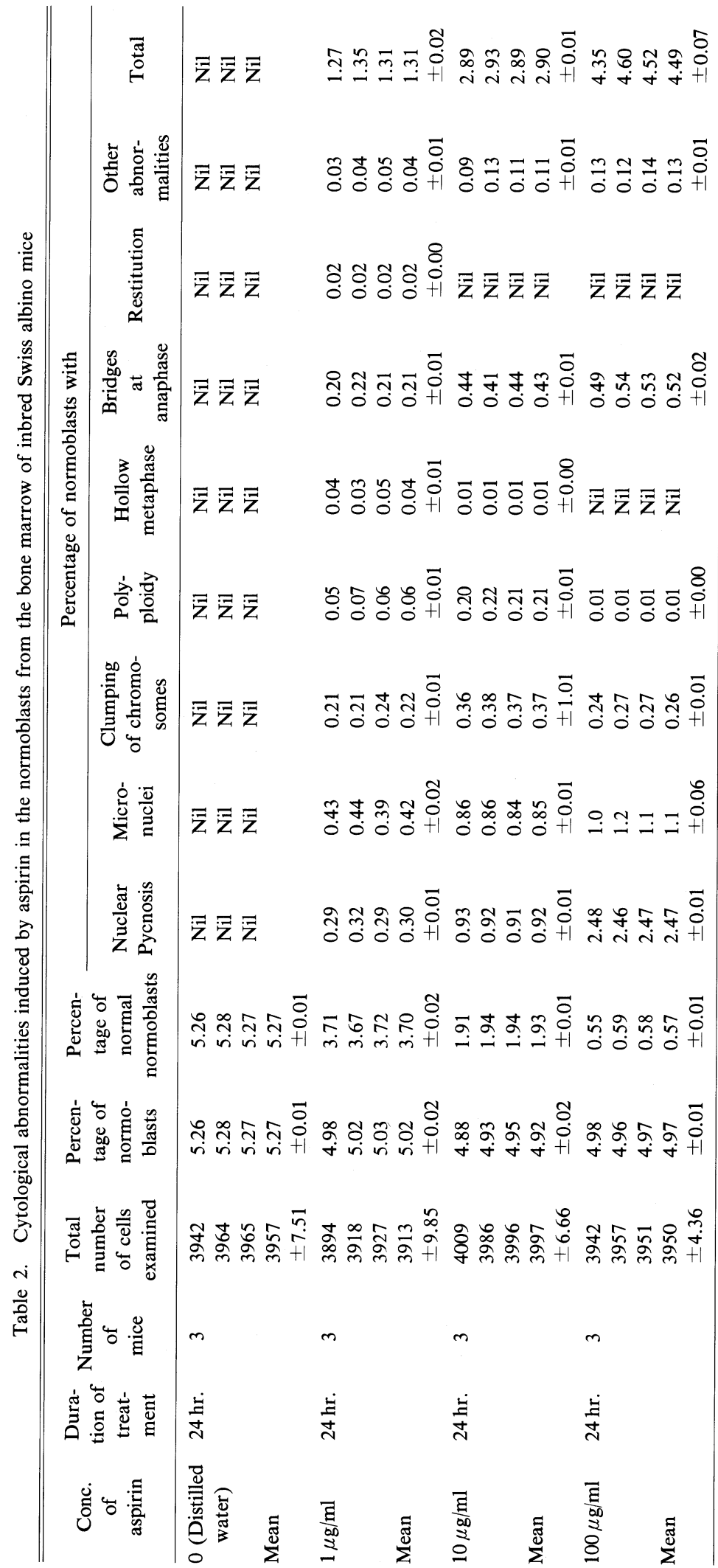


before nuclear membrane dissolution results in endomitosis and blockage at metaphase results in C-mitosis.

As the polyploid numbers of condensed chromosomes presently observed were not limited by the nuclear membrane, these would have been formed by mitotic arrest at metaphase as caused by colchicine and vinca alkaloids (Biesele 1958, Deysson 1968). Acute arrests at prometaphase and metaphase would have resulted in chromosome clumping, hollow metaphase and highly pycnotic nuclei. Moreover, the drug was capable of arresting mitosis at anaphase and early telophase stages resulting in the formation of irregular pycnotic daughter nuclei. These abnormalities were also noticed in treatment with another antipyretic and analgesic drug, analgin (Meenakumari and Stephen 1995). In fact, many of the miotic poisons are capable of causing these abnormalities (Biesele 1958, Deysson 1968). Shanthamurthy and Rangaswamy (1979) had reported mitotic spindle abnormalities induced by aspirin in Allium cepa.

Regarding the clastogenic potentiality, aspirin is capable of causing chromosome fragmentation and the formation of micronuclei. Bone marrow micronucleus test (Schmid 1975, Maier and Schmid 1976) has been approved as a reliable test for the clastogenicity of chemicals. Mouse bone marrow chromosome assay is also a standard short-term clastogenicity assay (Larramendy et al. 1980). Besides these, chromosome stickiness and sticky bridges were encountered in treated materials. According to Klasterska et al. (1976), sticky bridges at anaphase represent subchromatid aberrations. Many of these chromosomal aberrations reported to be induced by other clastogenic chemicals (Kihlman 1966). The acute pulverization of almost all the chromosomes in the bone marrow cells resulting in the formation of numerous chromatin globules as presently observed has been reported in $A$. cepa cells treated with the antineoplastic drug Adriamycin (Mercykutty and Stephen 1980) and points out to the possibility of the destruction of bone marrow cells upon aspirin administration and hence bone marrow depression. Griffin and D'Arcy (1979) had mentioned about the deleterious effect of aspirin on platelet function. Gilman et al. (1991) have commented: "Despite the efficacy and safety of aspirin as an analgesic and antirheumatic agent, it is necessary to be aware of its role in Reye's syndrome and a common cause of lethal drug poisoning in children, as well as its potential for serious toxicity, if used improperly." Even though the drug may be highly useful in the prevention or management of cardio-vascular diseases (Juul-Moller et al. 1992), the presently observed highly mitoclastic and clastogenic effects induced in mouse bone marrow cells, coupled with the reports of carcinogenic properties exhibited by this drug (Odashima 1976, Nesnow et al. 1987, IARC 1987) demand for the abolition of indiscriminate use of this drug without medical prescription.

\section{Summary}

One $\mathrm{ml}$ each of sterile aqueous solutions of aspirin (acetyl salicylic acid) at $1 \mu \mathrm{g} / \mathrm{ml}, 10$ $\mu \mathrm{g} / \mathrm{ml}$ and $100 \mu \mathrm{g} / \mathrm{ml}$ were injected intraperitoneally into different inbred Swiss albino mice of about $30 \mathrm{~g}$ weight. After $24 \mathrm{hr}$, bone marrow was extracted from the femurs and cytological preparations were made. There was a marked depression in the mitotic indices of the bone marrow cells, in treated mice corresponding to the concentration of aspirin compared to that of controls. Mitotic arrests and apindle abnormalities were also encountered. The drug was also capable of inducing chromosome fragmentation, pulverization, stickiness and sticky bridges. These observation clearly show that aspirin is both mitoclastic and clastogenic even at very low concentrations, and hence its indiscriminate use has to be discouraged. 


\section{Acknowledgements}

This work was done at the Cytogenetics Laboratory of the Department of Botany, University of Kerala, Kariavattom and the authors are indebted to Dr. (Mrs) Susan Abraham, then Professor and Head of the Department for extending facilities and encouragements. Sailas Benjamin is thankful to CSIR, Govt. of India for a research fellowship.

\section{References}

Biesele, J. J. 1958. Mitotic Poisons and the Cancer Problem. Elsevier Pub. Co. Houston.

Deysson, G. 1968. Antimitotic substances. Int. Rev. Cytol. 24: 99-148.

Gilman, A. G., Rall, T. W., Nies, A. S. and Taylor, P. 1991. The Pharmacological Basis of Therapeutics, 8th edn. Pergamon Press, New York, Oxford, pp. 644-653.

Griffin, J. P. and D’Arcy, P. F. 1979. A Manual of Adverse Drug Interactions, 2nd edn. John Wright and Sons Ltd., Bristol, p. 216.

IARC 1987. Analgesic mixtures containing phenacetin. IARC Monographs on the Evaluation of Carcinogenic Risks of Chemicals to Humans. Updating of IARC Monographs Vol. 1 to 42, Suppl. 7, IARC Lyon, pp. 310-312.

Juul-Moller, S., Edvardsson, N., Jahnmatz, B., Rosen, A., Sorensen, S. and Omblus, R. 1992. Double blind trial of aspirin in primary prevention of myocardial infarction in patients with stable chronic angina pectoris. Lancet 340: $1421-1424$.

Kihlman, B. A. 1966. Action of Chemicals on Dividing Cells. Prentice Hall-Engelwood Cliff, New Jersey.

Klasterska, I., Natarajan, A. T. and Ramel, C. 1976. An interrelation of the origin of subchromatid aberrations and chromosome stickiness as a category of chromatid aberrations. Hereditas 83: 153-169.

Kune, G. A., Kune, S. and Watson, L. F. 1988. Colorectal cancer risk, chronic illness, operations and medicines: case control results from Melbourne colorectal cancer study. Cancer Res. 48: 4399-4404.

Larramendy, M. L., Dulout, F. N., Bianchi, N. O. and Olivero, O. A. 1980. In vivo dose response relationship in bone marrow cells of mice treated with adriamycin. Mut. Res. 79: 133-140.

Maier, P. and Schmid, W. 1976. Ten model mutagens evaluated by the micronucleus test. Mut. Res. 40: 325-388.

Marnett, L. J. 1992. Aspirin and the potential role of prostaglandins in colon cancer. Cancer Res. 52: 5575-5589.

McCredie, M., Stewart, J. H. and Day, N. E. 1993. Different roles for phenacetin and paracetamol in cancer of the kidney and renal pelvis. 1993, Int. J. Cancer 53: 245-249.

Meenakumari, T. and Stephen, J. 1995. Mitoclastic and Clastogenic properties of analgin. J. Cytol. Genet. 30: 27-33.

Mercykutty, V. C. and Stephen, J. 1980. Adriamycin induced genetic toxicity as demonstrated by the Allium test. Cytologia 45: 769-777.

Nagl, W. 1970. The mitotic and endomitotic nuclear cycle in Allium carinatum, Relationship between DNA replication and chromatin structure. Cytologia 23: 71-78.

Nesnow, S., Argus, M., Bergman, H., Chu, K., Frith, C., Helmer, T., McGaughty, R., Ray, V., Slaga, T. J., Tennant, R. and Weishburgher, E. 1987. Chemical carcinogens: a report of the U.S. Environmental Protection Agency, Genetic Toxicology Programme. Mut. Res. 185: 1-195.

Odashima, S. 1976. The cooperative development in japan of methods for screening chemicals for carcinogenicity. In: Screening Tests in Chemical Carcinogenesis. (eds) R. Montesano, H. Bartsch and L. Tomatis. IARC, Lyon pp. 61-79.

Schmid, W. 1975. The micronucleus test. Mut. Res. 31: 9-15.

Shanthamurthy, B. K. and Rangaswamy, V. 1979. Mitotic spindle irregularities induced by aspirin in Allium cepa. Curr. Sci. 48: 1039-1041.

Stephen, J., Mohankumar, P., Ravindran Ankathil, Mercykutty, V. C., Shakkeela, N., Mary Chacko, Babu, N., Meenakumari, T., Pradeep Kumar. V., Annie Joy and Sailas Benjamin 1995. Genetic toxicology of some therapeutic drugs. Proc. Ann. Conf. Int. Med. Sci. Acad. (12-15 March, 1994), Trivandrum, India.

Thun, M. J., Namboodiri, M. M. and Heath, C. W. Jr. 1991. Aspirin use and reduced risk of fatal colon cancer. N. Engl. J. Med. 3225: 1593-1596.

Weissmann, G. 1991. Aspirin. Sci. Am. Jan. 1991. pp. 58-64. 